\title{
Analisa Perbandingan Metode Profile Matching Dan Topsis Dalam Pemilihan Ketua OSIS
}

\author{
Zul Hisyam ${ }^{1}$, Prabowo Budi Utomo ${ }^{2}$ \\ ${ }^{1)}{ }^{2)}$ Magister Teknik Informatika, Fakultas Teknik Informatika, Universitas Amikom Yogyakarta \\ Email: ${ }^{1)}$ zu10342@gmail.com, ${ }^{2)}$ prabowo.utomo@students.amikom.ac.id
}

\begin{abstract}
Abstrak
Pemilihan ketua OSIS merupakan agenda tahunan yang diselenggarakan oleh setiap sekolah sebagai media pembelajaran bagi siswa dalam berdemokrasi dan menentukan pilihannya. Didalam pemilihan ketua OSIS diperlukan banyak tahapan dan persiapan yang perlu dilakukan mulai dari pendaftaran, sosialisasi program sampai tahap pemilihan dan perhitungan yang memerlukan banyak tenaga dan biaya. Seringkali hasil dari pemilihan menetapkan/memilih siswa yang secara kecakapan kurang memenuhi namun terpilih lebih karena kepopulerannya. Berdasar pada permasalahan tersebut maka diperlukan metode tertentu untuk mendapatkan rekomendasi ketua OSIS yang sesuai dengan kriteria yang diharapkan. Penggunaan Metode Topsis dan Profile Matching mampu memberikan rekomendasi berdasar pada kriteria yaitu Prestasi Akademik, Kedisiplinan, Sikap \& Perilaku, Pergaulan dan Usia. Kemudian dari hasil yang dihasilkan oleh kedua metode tersebut akan dibandingkan accuracy nya. Dari perhitungan yang dilakukan metode Profile Matching mampu nilai yang lebih tinggi yaitu sebesar 4.6 dengan akurasi 92.5\%, sedang metode Topsis menghasilkan akurasi 80,96\%.
\end{abstract}

Kata kunci:pemilihan, Ketua OSIS, Topsis, Profile Matching

\begin{abstract}
The selection of the student council president is an annual agenda organized by each school as a medium of learning for students in democratizing and making choices. In the election of the student council president, many stages and preparations needed to be done starting from registration, program socialization to the selection stage and calculations that require a lot of energy and costs. Often the results of the elections determine / choose students who are less fulfilling skills but are chosen more because of their popularity. Based on these problems, a certain method is needed to get the recommendations of the student council president in accordance with the expected criteria. The use of the Topsis Method and Profile Matching is able to provide recommendations based on the criteria namely Academic Achievement, Discipline, Attitude \& Behavior, Relationship and Age.

Then the results produced by both methods will be compared to its accuracy. From the calculations performed the Profile Matching method is capable of a higher value of 4.6 with an accuracy of $92.5 \%$, while the Topsis method produces an accuracy of $80.96 \%$.
\end{abstract}

Keywords: election, Chairperson of Student Council, Topsis, Profile Matching

\section{PENDAhUluAN}

Pemilihan ketua OSIS sebagai kegiatan tahunan merupakan suatu kegiatan pembelajaran yang dilakukan oleh sekolah dalam upaya untuk meningkatkan pengetahuan siswa tentang berdemokrasi dan menentukan pilihannya. Pemilihan Ketua OSIS juga bertujuan untuk menentukan siswa yang mampu memimpin siswa yang lainnya terutama dalam berorganisasi, melakukan kegiatan yang terencana dan terkoordinasi serta mampu menjadi komunikator yang baik antara sekola dengan siswa. Melihat hal tersebut diperlukan beberapa kriteria yang mencakup kecakapan yang diharapkan dari Ketua OSIS.

Didalam pemilihan Ketua OSIS biasanya disertakan beberapa persyaratan yang menjadi kriteria yang harus dipenuhi untuk menjadi ketua OSIS. Kriteria tersebut diantaranya Prestasi Akademik, Kedisiplinan, 
Sikap \& Perilaku, Pergaulan dan Usia. Siswa yang terpilih diharapkan mampu memenuhi kriteria tersebut sehingga akan didapatkan Ketua OSIS yang cakap dalam berbagai bidang. Walaupun sudah ditentukan kriterianya namun sering Ketua OSIS yang terpilih belum memiliki kecapakan seperti yang diharapkan. Faktor seperti popularitas atau kemampuan untuk merayu membuat banyak ketua OSIS yang terpilih belum sesuai dengan harapan. Berdasar pada permasalahan tersebut maka diperlukan sebuah mekanisme untuk memilih Ketua OSIS sehingga dapat diperoleh ketua OSIS yang sesuai dengan kriteria dan harapan.

Mekanisme untuk memilih Ketua OSIS dapat dibangun dengan menggunakan algoritma TOPSIS (Technique for Order Performance by Similarity to Ideal Solution) dan Profile Matching. Konsepnya yang sederhana, mudah dipahami serta kemampuannya untuk mengukur kinerja relatif dari alternatif keputusan yang ada serta mampu menyajikan dalam bentuk matematis sederhana membuat kedua algoritma ini cukup sesuai sebagai media analisa dalam pemilihan Ketua OSIS. Dengan hal ini diharapkan kedua metode ini mampu membandingkan satu calon ketua OSIS dengan calon Ketua OSIS lainnya satu persatu, sehingga akan diketahui mana calon yang lebih memenuhi kritria yang telah ditentukan, perbandingan ini juga diharapkan akan meningkatkan presisi menjadi lebih baik.

\section{TINJAUAN PUSTAKA}

\section{a. Sistem Pendukung Keputusan}

Sistem Pendukung Keputusan (SPK) merupakan suatu sistem informasi berbasis komputer yang menghasilkan berbagai alternatif keputusan untuk membantu dalam menangani suatu permasalahan yang terstruktur maupun tidak terstruktur. Tujuan adanya SPK, untuk mendukung pengambil keputusan dengan memilih alternatif hasil pengolahan informasi dengan model-model pengambil keputusan serta untuk menyelesaikan masalah yang bersifat semi terstruktur dan tidak terstruktur (Putra dkk., 2015)

\section{b. Algoritma TOPSIS}

TOPSIS merupakan salah satu metode pengambilan keputusan multikriteria yang menjadi pengembangan dari metode AHP (Kahraman, 2008). TOPSIS menggunakan prinsip bahwa alternatif yang terpilih harus mempunyai jarak terdekat dari solusi ideal positif dan terjauh dari solusi ideal negatif dari sudut pandang geometris dengan menggunakan jarak Euclidean untuk menentukan kedekatan relative dari suatu alternatif dengan solusi optimal.

Solusi kompromi dapat dianggap sebagai pemilihan solusi dengan jarak euclidean terdekat dari solusi ideal positif dan jarak euclidean terjauh dari solusi ideal negatif (Tzeng \& Huang, 2011).

Metode TOPSIS memiliki beberapa kelebihan, diantaranya adalah konsepnya sederhana dan mudah dipahami, komputasinya efisien, serta memiliki kemampuan untuk mengukur kinerja relatif dari alternative keputusan dalam bentuk matematis yang sederhana. Metode ini banyak digunakan untuk menyelesaikan pengambilan keputusan secara praktis. Langkah - langkah yang dilakukan dalam mendapatkan solusi yang memiliki jarak terpendek dari solusi ideal positif dan memiliki jarak terjauh dari solusi ideal negative adalah sebagai berikut :

1) Membuat matriks keputusan yang ternomalisasi.

2) Membuat matriks keputusan yang ternormalisasi terbobot;

3) Menentukan matriks solusi ideal positif dan matriks solusi ideal negative

4) Menentukan jarak antara nilai setiap alternatif dengan matriks solusi ideal positif dan matriks solusi ideal negative

5) Menentukan nilai preferensi untuk setiap alternatif.

Metode TOPSIS membutuhkan matriks yang ternormalisasi pada setiap kriteria, yang dapat diperoleh dengan rumus

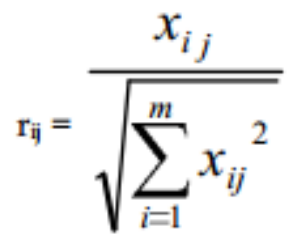

Dengan $I=1,2, \ldots, m ;$ dan $j=1,2, \ldots, n$; dimana :

$\mathrm{r}_{\mathrm{ij}}=$ Matriks ternormalisasi

$\mathrm{x}_{\mathrm{ij}}=$ Matriks Keputusan 
Solusi ideal positif $\mathrm{A}^{+}$dan solusi ideal negatif $\mathrm{A}^{-}$dapat ditentukan berdasarkan rating bobot ternormalisasi (y ij) sebagai :

yij = wi.rij ; dengan $\mathrm{i}=1,2, \ldots, \mathrm{m} ;$ dan $\mathrm{j}=1,2, \ldots, \mathrm{n}$

$$
\begin{aligned}
& \mathrm{A}^{+}=\left(\mathrm{y}_{1}^{+}, \mathrm{y}_{2}^{+}, \ldots, \mathrm{y}_{\mathrm{n}}^{+}\right) ; \\
& \mathrm{A}^{-}=\left(\mathrm{y}_{1}^{-}, \mathrm{y}_{2}^{-}, \ldots, \mathrm{y}_{\mathrm{n}}\right) ;
\end{aligned}
$$

Dimana :

yij = matriks ternormalisasi terbobot $[\mathrm{i}][\mathrm{j}]$

wi $=$ vektor bobot [i] dari proses AHP

$\mathrm{yj}^{+}=\max \mathrm{y}_{\mathrm{ij}}, \quad \mathrm{jika} \mathrm{j}$ adalah atribut keuntungan

min $\mathrm{y}_{\mathrm{ij}}$, jika $\mathrm{j}$ adalah atribut biaya

$\mathrm{yj}^{-}=\min \mathrm{y}_{\mathrm{ij}}, \quad$ jika $\mathrm{j}$ adalah atribut keuntungan

max $y_{i j}, j i k a j$ adalah atribut biaya

$\mathrm{j}=1,2, \ldots, \mathrm{n}$

sedangkan jarak alternatif dari $A_{i}$ dengan solusi ideal positif dihitung dengan rumus

$$
\mathrm{D}_{\mathrm{i}}^{+}=\sqrt{\sum_{i=1}^{n}\left(y_{i}^{+}-y_{i j}\right)^{2}} ; \quad \mathrm{i}=1,2, \ldots, \mathrm{m}
$$

dimana :

$\mathrm{D}_{\mathrm{i}}^{+}=$jarak alternatif Ai dengan solusi ideal positif

$\mathrm{Y}_{\mathrm{i}}^{+}=$solusi ideal positif $[\mathrm{i}]$

$y_{i j}=$ matriks normalisasi terbobot $[i][j]$

untuk Jarak antara alternatif Ai dengan solusi ideal negatif dihitung dengan rumus

$$
\mathrm{D}_{\mathrm{i}}^{*}=\sqrt{\sum_{j=1}^{n}\left(y_{i j}-y_{i}^{-}\right)^{2}} \quad ; \mathrm{i}=1,2, \ldots, \mathrm{m}
$$

dimana :

$\mathrm{D}_{\mathrm{i}}^{+}=$jarak alternatif Ai dengan solusi ideal positif

$\mathrm{Y}_{\mathrm{i}}{ }^{+}=$solusi ideal positif[i]

$\mathrm{y}_{\mathrm{ij}}=$ matriks normalisasi terbobot[i][j]

Nilai preferensi untuk setiap alternatif (Vi) dapat dilihat pada rumus

$$
\mathrm{Vi}=\frac{D_{i}^{-}}{D_{i}^{-}+D_{i}^{+}} ; \mathrm{i}=1,2, \ldots, \mathrm{m}
$$

dimana :

$\mathrm{V}_{\mathrm{i}} \quad=$ kedekatan tiap alternatif terhadap solusi ideal

$\mathrm{D}_{\mathrm{i}}^{+} \quad=$ jarak alternatif Ai dengan solusi ideal positif

$\mathrm{D}_{\mathrm{i}}^{-} \quad=$ jarak alternatif Ai dengan solusi ideal negatif

Nilai $V_{i}$ yang paling besar yang menunjukkan bahwa alternatif tersebut yang dipilih.

\section{c. Algoritma Profile Matching}

Gap Kompetensi atau Profile Matching merupakan mekanisme dalam pengambilan keputusan dengan mengasumsikan bahwa terdapat input profil ideal yang harus dipenuhi oleh subyek yang diteliti, bukannya tingkat minimal yang harus dipenuhi atau dilewati.

Secara garis besar profile matching merupakan proses membandingkan antara nilai data actual dari suatu profile yang akan dinilai dengan nilai profil yang diharapkan, sehingga dapat diketahui perbedaan kompetensinya (disebut juga gap), semakin kecil gap yang dihasilkan maka bobot nilainya semakin besar yang berarti memiliki peluang lebih besar untuk direkomendasikan untuk terpilih. Didalam metode profile matching dikenal istilah Core factor yang merupakan aspek (kompetensi) yang paling menonjol/paling dibutuhkan yang diperkirakan dapat menghasilkan kinerja optimal dan Secondary factor adalah item-item selain aspek yang ada pada core factor yang mendukung upaya memperoleh kinerja optimal.

Menurut (Kusrini, 2008) tahapan dalam metode profile matching adalah sebagai berikut:

1) Menentukan bobot nilai gap

2) Langkah kedua dengan melakukan pemetaan Gap

3) Melakukan pencocokan dengan tabel bobot

4) Melakukan perhitungan core factor dan secondary factor

5) Perhitungan nilai total

6) Perhitungan penentuan rangking.

\section{d. Confusion Matrix}

Confusion Matrix adalah metode yang biasanya digunakan sebagai perhitungan akurasi konsep data mining. Informasi dalam Confusion Matrix diperlukan untuk menentukan kinerja model klasifikasi, atau untuk membandingkan kinerja model yang berbeda. Confusion Matrix terbagi dalam 4 model pengukuran yaitu Akurasi, Presisi, Penarikan dan $F$-measure.

1) Akurasi/Accuracy

Perhitungan akurasi dilakukan dengan membagi jumlah data dan klasifikasi dengan benar dengan total sampel data uji yang diuji.

$$
\text { Accuracy }=\frac{T P+T N}{T P+T N+F P+F N}
$$




\section{2) Presisi/Precision}

Perhitungan presisi dilakukan dengan membagi nilai positif sejati dari data benar dibagi dengan jumlah data positif benar dan data negatif palsu (false negative).

$$
\text { Precision }=\frac{T P}{T P+F P}
$$

\section{3) Penarikan/Recall}

Perhitungan Recall dilakukan dengan membagi data positif benar (positif) dengan jumlah data positif benar (benar positif) dan data negatif negatif (salah negatif).

$$
\text { Recall }=\frac{T P}{T P+F N}
$$

\section{4) F-Measure}

Nilai ini diperoleh dari perhitungan pembagian hasil perkalian dari presisi dan recall dengan jumlah presisi dan recall kemudian dikalikan dua.

$$
f-\text { Measure }=2 * \frac{\text { precision } * \text { recall }}{\text { precision }+ \text { recall }}
$$

\section{Rancangan Sistem}

Proses pemilihan Ketua OSIS menggunakan algoritma TOPSIS dan Profile Matching digambarkan dengan langka - langkah dalam proses penginputan data sampai mendapatkan perbandingan nilai akurasi sebagaimana yang ditunjukkan pada Gambar 1 berikut.

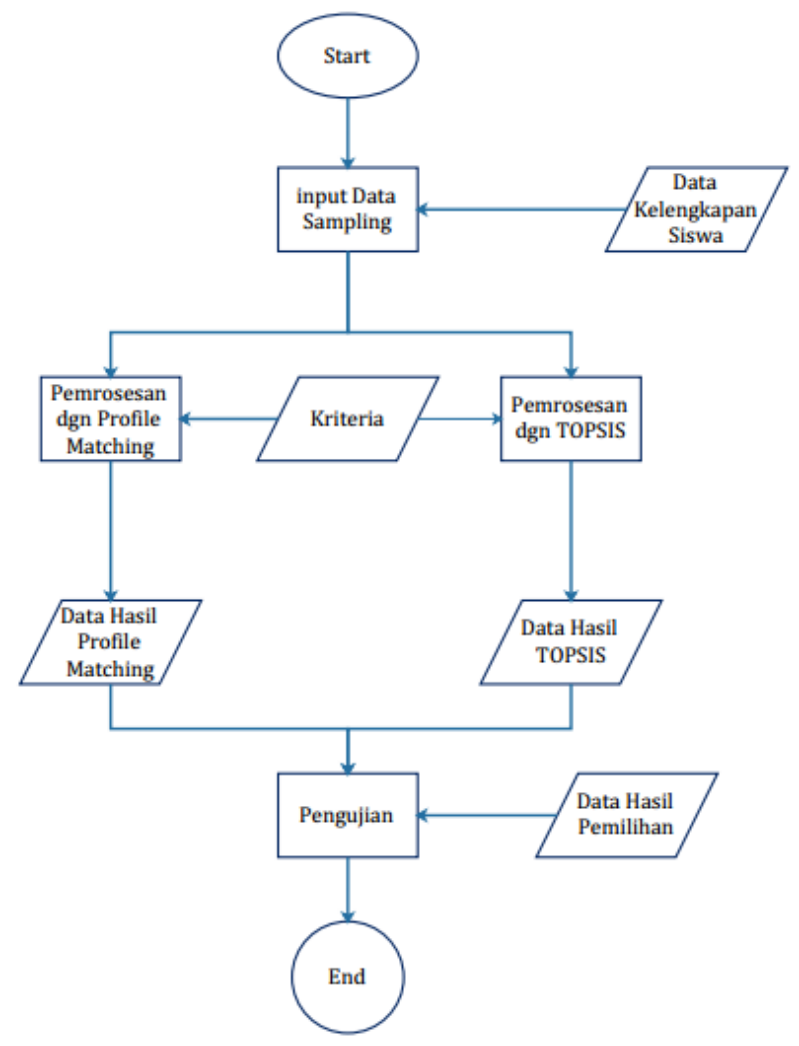

Gambar 1. Alur Proses Pemilihan Ketua OSIS

Berdasar pada Gambar 1 diatas proses diawali dengan pengiputan data yang bersumber dari profile siswa. Data tersebut terlah melalui proses Normalisasi data dimana data dirubah menjadi data numerik melalui proses konversi dengan nilai yang sudah ditentukan dalam kriteria. Selanjutnya data diuji menggunakan 2 metode yaitu TOPSIS dan Profile Matching untuk kemudian masingmasing data yang dihasilkan diuji secara dibanding dengan alur sebagaimana ditunjukkan pada Gambar 2 berikut. 


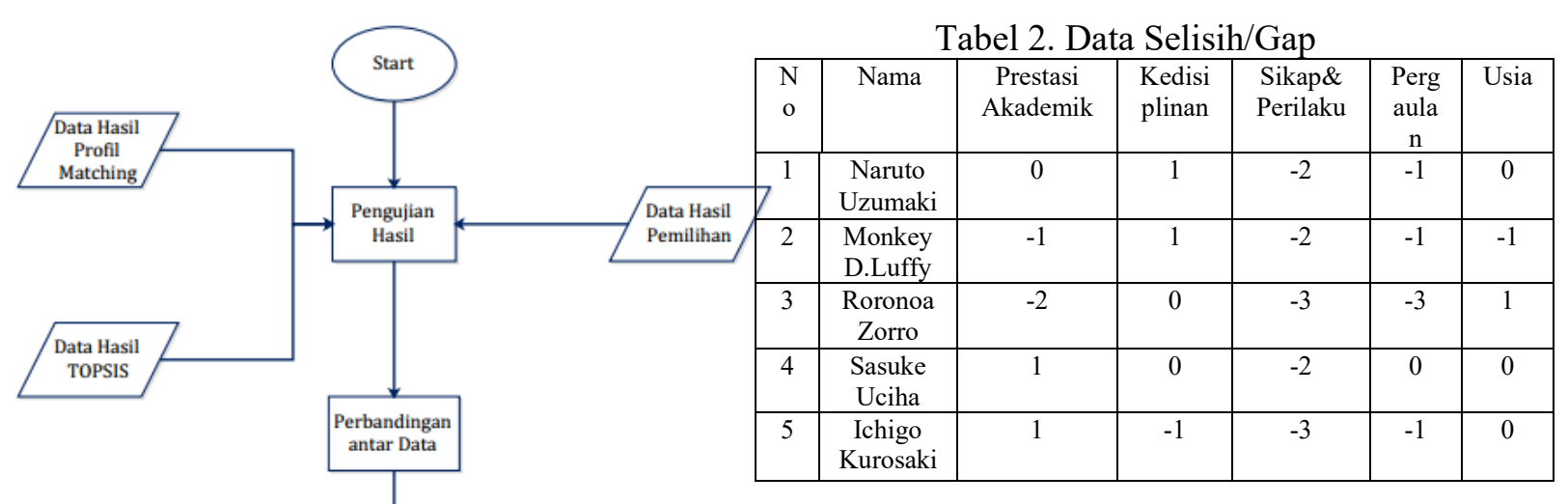

Data pada Tabel 2 diatas akan dikonversi dengan nilai bobot sehingga didapatkan data seperti pada Tabel 3 berikut.

Tabel 3. Data Hasil konversi bobot

\begin{tabular}{|c|c|c|c|c|c|c|}
\hline $\begin{array}{c}\text { N } \\
\text { o }\end{array}$ & Nama & $\begin{array}{c}\text { Prestasi } \\
\text { Akademik }\end{array}$ & $\begin{array}{c}\text { Kedisi } \\
\text { plinan }\end{array}$ & $\begin{array}{c}\text { Sikap\& } \\
\text { Perilaku }\end{array}$ & $\begin{array}{c}\text { Perg } \\
\text { aula } \\
\mathrm{n}\end{array}$ & Usia \\
\hline 1 & $\begin{array}{c}\text { Naruto } \\
\text { Uzumaki }\end{array}$ & 5 & 4.5 & 3 & 4 & 5 \\
\hline 2 & $\begin{array}{c}\text { Monkey } \\
\text { D.Luffy }\end{array}$ & 4 & 4.5 & 3 & 4 & 4 \\
\hline 3 & $\begin{array}{c}\text { Roronoa } \\
\text { Zorro }\end{array}$ & 3 & 5 & 2 & 2 & 4.5 \\
\hline 4 & $\begin{array}{c}\text { Sasuke } \\
\text { Uciha }\end{array}$ & 4.5 & 5 & 3 & 5 & 5 \\
\hline 5 & $\begin{array}{c}\text { Ichigo } \\
\text { Kurosaki }\end{array}$ & 4.5 & 4 & 2 & 4 & 5 \\
\hline
\end{tabular}

Data hasil konversi pada tabel 3 selanjutnya dihitung untuk mencari nilai Core Factor dan Secondary Factor dengan menggunakan persamaan berikut :

$$
\begin{aligned}
& \text { Core Factor : NCF }=\frac{\sum N C \text { (aspek) }}{\sum I C} \\
& \text { Secondary Factor : NSF }=\frac{\sum N S \text { (aspek) }}{\sum I S}
\end{aligned}
$$

Sehingga akan menghasilkan data seperti pada Tabel 4 berikut.

\section{Tabel 4. Data Core Factor dan Secondary Factor}

Untuk kemudian data pada Tabel 4 akan dihitung Nilai Total yang berasal dari penjumlahan antara nilai core factor dan secondary factor seperti yang ditunjukkan pada Tabel 5 berikut.
Setelah didapatkan data hasil normalisasi maka dilakukan proses perhitungan dengan metode profile matching, dimana data hasil normalisasi dilakukan pengurangan dengan kriteria untuk mendapatkan data selisih/Gap, yang ditunjukkan pada Tabel 2 berikut. 
Tabel 5. Hasil Perhitungan Nilai Total

\begin{tabular}{|c|c|c|c|c|c|c|c|c|c|}
\hline $\begin{array}{l}\mathrm{N} \\
\mathrm{o}\end{array}$ & $\begin{array}{l}\mathrm{Na} \\
\mathrm{ma}\end{array}$ & $\begin{array}{c}\text { Prest } \\
\text { asi } \\
\text { Akad } \\
\text { emik }\end{array}$ & $\begin{array}{c}\text { Kedis } \\
\text { iplina } \\
n\end{array}$ & $\begin{array}{c}\text { Sik } \\
\text { ap } \\
\& \\
\text { Peri } \\
\text { lak } \\
\text { u }\end{array}$ & $\begin{array}{l}\text { Per } \\
\text { gau } \\
\text { lan }\end{array}$ & $\begin{array}{c}\text { Usi } \\
\text { a }\end{array}$ & $\begin{array}{l}C \\
F\end{array}$ & $\begin{array}{l}S \\
F\end{array}$ & $\begin{array}{c}N \\
T\end{array}$ \\
\hline 1 & $\begin{array}{c}\text { Nar } \\
\text { uto } \\
\text { Uzu } \\
\text { mak } \\
\text { i }\end{array}$ & 5 & 4.5 & 3 & 4 & 5 & $\begin{array}{c}4 . \\
1\end{array}$ & $\begin{array}{l}5 . \\
0\end{array}$ & $\begin{array}{l}4 . \\
6\end{array}$ \\
\hline 2 & $\begin{array}{c}\text { Mo } \\
\text { nke } \\
\text { y } \\
\text { D.L } \\
\text { uffy }\end{array}$ & 4 & 4.5 & 3 & 4 & 4 & $\begin{array}{l}3 . \\
9\end{array}$ & $\begin{array}{c}4 . \\
0\end{array}$ & $\begin{array}{l}4 . \\
5\end{array}$ \\
\hline 3 & $\begin{array}{c}\text { Ror } \\
\text { ono } \\
\text { a } \\
\text { Zorr } \\
\text { o }\end{array}$ & 3 & 5 & 2 & 2 & 4.5 & $\begin{array}{l}3 . \\
0\end{array}$ & $\begin{array}{c}4 . \\
5\end{array}$ & $\begin{array}{l}4 . \\
2\end{array}$ \\
\hline 4 & $\begin{array}{c}\text { Sas } \\
\text { uke } \\
\text { Uci } \\
\text { ha } \\
\end{array}$ & 4.5 & 5 & 3 & 5 & 5 & $\begin{array}{l}4 . \\
4\end{array}$ & $\begin{array}{c}5 . \\
0\end{array}$ & $\begin{array}{l}3 . \\
9\end{array}$ \\
\hline 5 & $\begin{array}{c}\text { Ichi } \\
\text { go } \\
\text { Kur } \\
\text { osa } \\
\text { ki } \\
\end{array}$ & 4.5 & 4 & 2 & 4 & 5 & $\begin{array}{l}3 . \\
6\end{array}$ & $\begin{array}{c}5 . \\
0\end{array}$ & $\begin{array}{l}3 . \\
6\end{array}$ \\
\hline
\end{tabular}

Berdasar pada Tabel 5 maka Nilai Total yang paling tinggi (4.6) menjadi rekomendasi ketua OSIS yang terpilih.

Pada proses dengan metode TOPSIS data hasil Normalisasi yang didapatkan pada Tabel 1 selanjutnya akan dilakukan proses perhitungan Matrik ternormalisasi, dengan hasil sebagaimana ditunjukkan tabel 6 berikut.

Tabel 6. Data Matriks Normalisasi

\begin{tabular}{|l|l|r|r|r|}
\hline r11 - r41 & \multicolumn{1}{|c|}{$\mathbf{r 1 2}-\mathbf{r 4 2}$} & $\mathbf{r 1 3}-\mathbf{r 4 3}$ & $\mathbf{r 1 4}-\mathbf{r 4 4}$ & \multicolumn{1}{c|}{ r15 - r55 } \\
\hline 0.442325868 & 0.544331054 & 0.534522484 & 0.452267017 & 0.441726104 \\
\hline 0.294883912 & 0.544331054 & 0.534522484 & 0.452267017 & 0.331294578 \\
\hline 0.147441956 & 0.40824829 & 0.267261242 & 0.150755672 & 0.55215763 \\
\hline 0.589767825 & 0.40824829 & 0.534522484 & 0.603022689 & 0.441726104 \\
\hline 0.589767825 & 0.272165527 & 0.267261242 & 0.452267017 & 0.441726104 \\
\hline
\end{tabular}

Data pada Tabel 6 selanjutnya akan dikalikan dengan nilai bobot untuk mendapatkan data matrik terbobot, sebagaimana ditunjukkan tabel 7 berikut.

Tabel 7. Data Matrik Terbobot

\begin{tabular}{|c|c|c|c|c|}
\hline C1 & C2 & C3 & C4 & C5 \\
\hline 1.326977605 & 1.632993162 & 2.138089935 & 1.809068067 & 1.766904417 \\
\hline 0.884651737 & 1.632993162 & 2.138089935 & 1.809068067 & 1.325178313 \\
\hline 0.442325868 & 1.224744871 & 1.069044968 & 0.603022689 & 2.208630521 \\
\hline 1.769303474 & 1.224744871 & 2.138089935 & 2.412090757 & 1.766904417 \\
\hline 1.769303474 & 0.816496581 & 1.069044968 & 1.809068067 & 1.766904417 \\
\hline
\end{tabular}

Data matrik terbobot selanjutnya akan dihitung nilai matriks solusi ideal positif $\&$ matriks solusi ideal negatif, sehingga dapat dihitung nilai Distence Jarak Ideal Positif \& Negatif, sebagaimana ditunjukkan pada Tabel 8 berikut.
Tabel 8. Data jarak ideal positif \& negatif

\begin{tabular}{|r|c|r|c|}
\hline Distence + & D+ & Distence & D- \\
\hline D1 $^{+}=$ & 0.868568068 & D1 $^{-}=$ & 2.05956304 \\
\hline D2 $^{+}=$ & 1.070628348 & D2 $^{\circ}=$ & 2.05917684 \\
\hline D3 $^{+}=$ & 2.66900889 & D3 $^{\circ}=$ & 0.40824829 \\
\hline D4 $^{+}=$ & 0.601488668 & D4 $^{-}=$ & 2.55699875 \\
\hline D5 $^{+}=$ & 1.538922391 & D5 $^{\circ}=$ & 1.84676392 \\
\hline
\end{tabular}

Setelah didapatkan data jarak ideal seperti pada tabel 8 maka dapat dihitung nilai Vektor (Vi) masing - masing, dimana nilai Vektor ini akan menjadi dasar dalam menentukan rekomendasi yang diberikan sistem, hasil dari perhitungan sebagaimana ditunjukkan pada Tabel 9 berikut.

Tabel 9. Hasil Perhitungan nilai Vektor

\begin{tabular}{|c|l|l|}
\hline Vektor & \multicolumn{1}{|c|}{ Hasil } & \multicolumn{1}{c|}{ Alternatif } \\
\hline V1 & 0.703371182 & Naruto Uzumaki \\
\hline V2 & 0.657924923 & Monkey D. Luffy \\
\hline V3 & 0.132666289 & Roronoa Zorro \\
\hline V4 & $\mathbf{0 . 8 0 9 5 6 4 3 3}$ & Sasuke Uchiha \\
\hline V5 & 0.545462205 & Ichigo Kurosaki \\
\hline
\end{tabular}

Nilai vector yang terbesar $\mathbf{( 0 . 8 0 9 5 6 4 3 3 )}$ menjadi rekomendasi Ketua OSIS yang terpilih.

Dari metode dan implementasi yang digunakan di aplikasikan kesbuah aplikasi berbasis web dalam menganalisis pemilihan ketua OSIS, berikut beberapa screenshoot dari aplikasi pemilihan ketua OSIS.

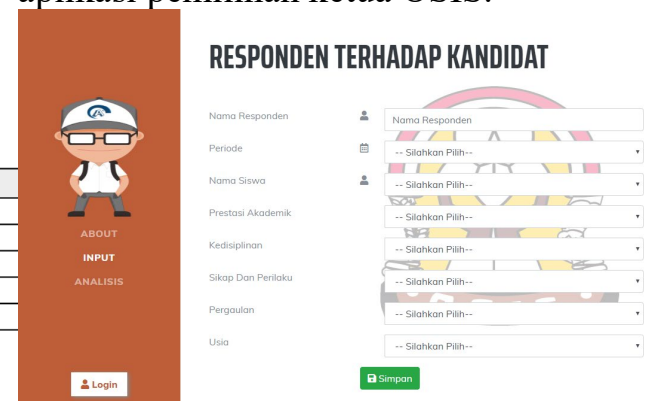

Gambar 3. Halaman Input Responden

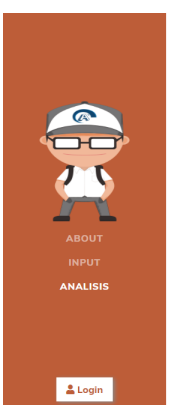

ANALISIS

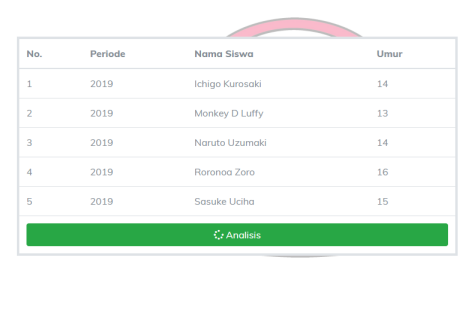

Gambar 4. Halaman Analisis 


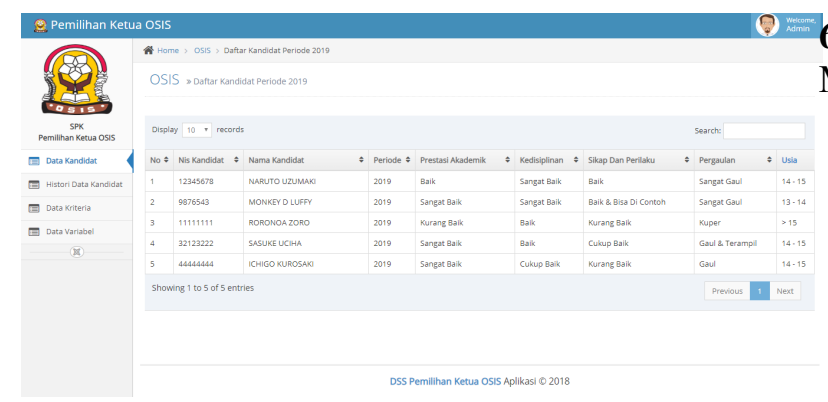

Gambar 5. Halaman Administrator

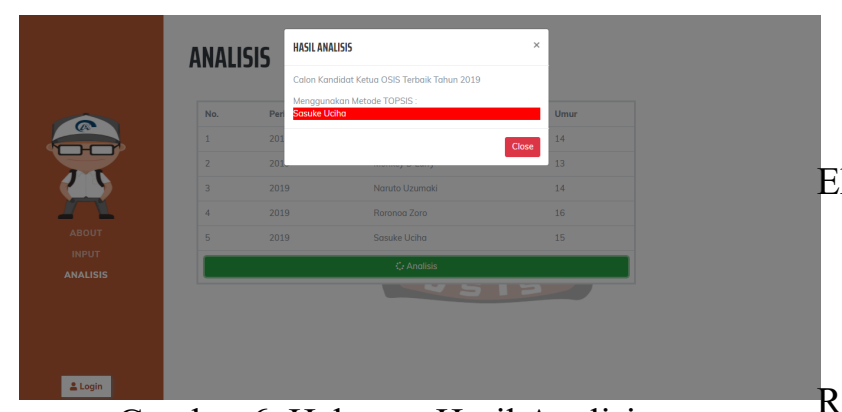

Gambar 6. Halaman Hasil Analisis

\section{b. Hasil}

Berdasar pada pengujian yang dilakukan dengan 2 metode yang berbeda ternyata menghasilkan rekomendasi yang sama namun dengan tingkat akurasi yang berbeda. Dengan menggunakan perhitungan accuracy pada Confusion Matrix diperoleh nilai akurasi untuk metode profile matching sebesar $92.5 \%$ sedang untuk metode TOPSIS sebesar $80.96 \%$.

\section{PENUTUP}

\section{a. Kesimpulan}

Kesimpulan dari penelitian ini adalah metode yang terbaik dalam merekomendasikan ketua osis berdasarkan pada kriteria Prestasi akademik, Kedisiplinan, Sikap \& Perilaku, Pergaulan, dan usia adalah menggunakan metode Profile Matching dengan tingkat akurasi sebesar $92,5 \%$

\section{b. Saran}

Saran untuk pengembangan sistem pada tahap selanjutnya adalah kemampuan penambahan kriteria yang lebih fleksibel serta pengembangan fitur yang lebih dinamis. Penggunaan metode perangkingan seperti weight product juga disarankan untuk mempermudah mengetahui hasil perhitungan yang direkomendasikan.
6. REFERENSI

Muhammad Irfan Nashrullah, Gunawan Abdillah, Faiza Renaldi. (2016). Sistem Pendukung Keputusan Untuk Rekomendasi Promosi Jabatan Menggunakan Metode Profile Matching dan Electre. Prosiding SNST ke-7 Fakultas Teknik Universitas Wahid Hasyim Semarang

Bustami. (2017). Sistem Pendukung Keputusan Pemilihan Mahasiswa Penerima Beasiswa Menggunakan Metode TOPSIS. Jurnal Penelitian Teknik Informatika Universitas Malikussaleh, Lhokseumawe Aceh.

Eka Sugiyarti, dkk. (2018). Decision Support System Of Scholarship Grantee Selection Using Data Mining. International Journal of Pure and Applied Mathematics. Volume 119 No. 15, 2239-2249.

Rivanda Putra Pratama, Indah Werdiningsih, Ira Puspitasari. (2017). Sistem Pendukung Keputusan Pemilihan Siswa Berprestasi di Sekolah Menengah Pertama dengan Metode VIKOR dan TOPSIS. Journal of Information Systems Engineering and Business Intelligence. Vol. 3, No. 2.

Abhishek Kumar, dkk. (2017). A review of multi criteria decision making (MCDM) towards sustainable renewable energy development. Renewable and Sustainable Energy Reviews 69. 596-609.

Cut Fiarni, Tamsir Sirait, Daniel Kelah. (2015). Sistem Pendukung Keputusan Pemilihan Siswa Olimpiade Sains Nasional Menggunakan Metode Profile Matching. Jurnal Sistem Informasi, Vol. 5, No. 3, hal. $208-217$. 